\section{Global emergencies}

W

hen a seismic Leviathan hurled a wave of death toward 11 countries on the rim of the Indian Ocean, a second wave swept through countries geographically exempt from this catastrophe. The outpouring of private, corporate and government donations for tsunami relief aid has been overwhelming. By January 5, pledges and donations from individual Canadians had topped $\$ 70$ million, and one agency - Médecins Sans Frontières - told supporters they had enough cash to satisfy their immediate plans for relief work. The sources of this response are many - humanitarianism, pure and simple; the terrible scale of an event that made the earth wobble; the familiarity of tourist havens now in ruins; the postprandial magnanimity of Boxing Week; for some, the loss of relatives and friends abroad; and a certain amount of diplomatic one-upmanship. Certainly, media exposure was key in unleashing this philanthropy: the staggering casualties, the scientific analyses (how fascinating this geologic mechanism of mass destruction), the video footage, testimonies of survivors, and photographs of the drowned, their arms raised against death.

Coverage of the event had much to do with numbers: the 9.0 of the Richter scale; the death toll, climbing daily by tens of thousands; the number of hours the tsunami travelled to each doomed shore (and the tragic lack of capacity for warning); the awesome comparisons with other "worst disasters" (such as the estimated 600000 killed by the 1976 earthquake in Tangshan, China, now lost to the collective memory of the West). And there were the tallies of donations, Canada's official response false-starting at $\$ 1$ million and rising to $\$ 425$ million as the enormity of the disaster dawned. No government agency or NGO needs to be told that when the first waves of shock and sympathy have subsided, financial and material support for the devastated regions must be sustained for years to come. At what point, one wonders, will "aid fatigue" set in? Victims of the earthquake in Bam, Iran, which killed 26000 on Boxing Day 2003, are still living in tents waiting for relief monies that were pledged.

And then there are the quieter numbers. According to a report released by UNAIDS in December, the number of people living with HIV worldwide has reached its highest level with an estimated 39.4 million people, up from an es$\approx$ timated 36.6 million in 2002. ${ }^{1}$ Of those infected, 7.1 million live in South and South-East Asia. The pandemic is gaining purchase in Eastern Europe and Asia, where injection drug use is also on the rise. Although UNAIDS also reports that "[g]lobal AIDS spending has tripled since 2001, from US\$2.1 billion in 2001 to US\$6.1 billion in 2004," in lowand middle-income countries, fewer than 1 in 5 people have access to HIV prevention services. ${ }^{2}$ Between 5 and 6 million infected people cannot get treatment. "Even though the number of those receiving treatment has more than doubled, less than $10 \%$ of people who need treatment, predominantly in sub-Saharan Aftica, are receiving it."

Thus WHO's director, Dr. Lee Jong-Wook, speaks of the need to "reinvigorate" HIV prevention and treatment efforts. This pandemic is a global catastrophe, and we must guard against donor fatigue - and against the "editorial fatigue" of news sources who turn their cameras away from stories after the shock value wears off. Media conglomerates have been pulling back from international reporting, closing foreign bureaus and reducing staff on the premise that Western audiences are not reliably interested in what happens on the other side of the world, except in the heat of a new disaster.

A countertrend to the business and spectacle of Big News coverage is the power of the Internet. This week we were copied on some email correspondence from a Canadian AIDS specialist working temporarily in Lesotho. Philip Berger describes the "intensity of illness and insufficiency of infrastructure" in a nation whose very existence is threatened by AIDS, and reminds us that "translating the Lesotho HIV epidemiology to Canada would mean 5.25 million 15-19 year olds and 350000 under 14-year olds infected with HIV." Perhaps if we let these particular numbers sink in, we will not lose sight of the chronic emergency that is AIDS, and redouble our efforts at relief.

Ironically, it was only a few weeks before the South Asian disaster that the Bush administration announced reductions in international food aid. The Canadian government has never succeeded in coughing up the $0.7 \%$ in international aid we pledged to the UN in 2001. The lack of a tsunami warning system for the Indian Ocean speaks to "years of underinvestment in the scientific and technical infrastructure needed to reduce the vulnerability of developing countries to ... calamity." ${ }^{3}$ We must not mistake disaster relief, no matter how generous, for the long-term, sustainable development assistance that is needed in hundreds of countries around the globe. - CMAf

\section{References}

1. UNAIDS. AIDS epidemic update - December 2004. Geneva: UNAIDS 2004. Available: www.unaids.org/wad2004/report.html (accessed 2005 Jan 5).

2. UNAIDS. Number of women living with HIV increases in each region of the world [press release]. Geneva: UNAIDS; 2004 Nov 23. Available: www.unaids.org /NetTools/Misc/DocInfo.aspx?LANG=en\&href=http://gva-doc-owl/WEBcontent /Documents/pub/Media/Press-Releases02/PR_EpiLaunch_23Nov04_en.pdf (accessed 2005 Jan 5).

3. Lerner-Lam A, Seeber L, Chen R. Simple science could have saved thousands. [commentary]. Los Angeles Times 2004;Dec 30. Available: www.latimes.com (accessed Jan 10 2005). 